\title{
Why Washington, DC, Is "One of the Best Places to Live in the World": An Interview with Tommy Wells, Director of the District Department of the Environment
}

\author{
By Christine Mellen
}

Tommy Wells is the director of the District Department of the Environment (DDOE). He first came to the District in 1983 after receiving his bachelor's degree from the University of Alabama and a master's degree in social work from the University of Minnesota. Wells focused on child welfare issues for over two decades, first at the city's child protective services agency and then as director of the Consortium for Child Welfare, a coalition of nonprofit organizations advocating for children, youth, and families in the District. During that time he attended law school at night, receiving his degree from the Catholic University of America in 1991.

Wells first held elected office in 1995, as a member of the Advisory Neighborhood Commission in Ward 6. Following a stint on the DC State Board of Education, he ran for city council, where he represented Ward 6 for eight years. During his time on the council, Wells sat on the committees responsible for legislation affecting the environment, health, human services, and transportation. In 2014, he ran in the Democratic primary for mayor, finishing third to current mayor Muriel Bowser and then-mayor Vincent Gray.

On March 18, Wells spoke with Christine Mellen of Policy Perspectives at his office. Their conversation touched on top- ics such as the District's disposable bag fee, energy and the environment, and the District's streetcar system.

Policy Perspectives: What attracted you to the field of social work generally and to the issue of child welfare specifically?

Tommy Wells: I wanted to do something that didn't put me into just one type of job. I'd thought about getting a doctorate in psychology, but in so many ways you would end up either just counseling or testing. I really wanted a broad experience, but I had a big interest in social psychology, how people lived, and how could you be helpful. So I knew early on I wanted to do something around helping people, and social work was broad enough to do many different things. I felt like I wasn't making too specific of a commitment, but a master's would allow me to do quite a bit. But I had a particular interest in adolescent health. When I went to Minnesota, I was at the university's medical center in a multidisciplinary team to do a fellowship on adolescent health. I had thought I was going to be a family therapist focused on badly behaving adolescents. And when I went to work in child welfare, I wanted to work on the unit with 
just teenagers, kids who are aging out and growing up through foster care. So that was the initial group I worked with. And what happened was the city in the late 1980s was going broke. It was the beginning of crack and HIV, and the social service system was collapsing. So I went to law school at night knowing I wanted another degree that would just give me more options in my life. I didn't want to get a doctorate in social work. From there, I realized I was more interested in changing systems than helping individuals one at a time.

PP: The five-cent disposable bag fee you helped create while on the council to encourage residents to "Skip the Bag, Save the River" has now been in effect for over five years. Residents report using fewer disposable bags since the fee took effect, but the revenue collected from it has been steady over time, suggesting the number of bags used has not continued to decrease. How do you interpret those findings?

TW: What I was looking for was a price point. What did we need in order to get someone to remember to bring bags or say, "You know what, for a nickel it's not worth taking a bag"? If you get chips and a soda and they say, "Do you want a bag?"-in your mind you're thinking, "That's another nickel, I'm about to eat and drink this right away, I don't need that." So the point was to find a price point that would get into your mind and then to get the rest of the city to embrace it and support it-so there would be legitimacy to charging for something people thought had been free-by dedicating the revenue to cleaning up the Anacostia River, an embarrassment, one of the dirtiest rivers in America. It worked very well almost immediately. That's one thing that was surprising. We achieved between a 60 and 65 percent reduction of plastic and paper bag usage almost right away. But we're not getting beyond 60 to 65 percent, apparently. What that tells you is, with the fivecent price point, there are still people who would rather take a bag. But for those who do, we raise $\$ 2$ million a year.

PP: What other pieces of legislation that you took the lead on during your tenure on the council do you think will have the most lasting impacts?

TW: When I first got on the council, I was given responsibility for chairing the committee on human services, and right off the bat we had a woman who starved and killed four of her children. It was a breakdown of our social service system. Even though the school's social worker was saying there's something wrong, the city failed them. So I had a very extensive hearing to figure out what went wrong. One thing I learned is the way people make reports to the child welfare system is all or none: either we decide that we need to go to your house and do a full investigation or not. There was a reluctance at times to take cases unless you were certain something was going on. So I changed that. I introduced a bill for what's called differential response that gave full legal support to saying that the agency can say, "There may be neglect or abuse, and we're going to call a neighborhood nonprofit to go check on you or talk to the school, but it doesn't require a full investiga- 
tion," which means they can handle more cases. Because what happened after that terrible case, there were so many reports of abuse and neglect, of people just reporting everything, that there was a backlog of months of investigations. By creating a differential response they were able to eliminate the backlog and at the same time protect children.

There are a number of other bills, but especially late, right before I came off the council. I passed the law and got through decriminalizing marijuana. That immediately changed lives, and now we'll see what happens with legalization. I created a sexual assault survivors bill that guarantees victims of sexual assault have an advocate with them at all times through the whole process, and the police department is required to have an outside auditor come in to evaluate how they're handling sexual assaults. We were one of the first jurisdictions in the country to deal with what's called civil asset forfeiture, which John Oliver made famous on his show. I changed that, and now that's a model for the rest of the country. That you could take people's stuff without ever charging them with a crime is just wrong. The kids in Anacostia, they called it the "hood tax." Police would just take their money.

When I had oversight of transportation, we had that beginning bikeshare program, and I said, "This is going to catch on." It made a lot of sense. So I ramped it up immediately, and by getting more stations around the city, it just was adopted. Then I helped usher in Car2Go, the whole idea of car sharing. I think that I had a major impact on rethinking transportation.
We'll have to see what happens, but I oversaw getting in at least the $\mathrm{H}$ Street line of the streetcar. The previous administrations had planned a streetcar and started building it while it was still against the law to have overhead wires. So I had to fight the battle to allow overhead wires, and that's the only reason they could go forward.

$P P$ : What are the advantages and disadvantages of now having a broader constituency but a narrower portfolio than you did as a councilmember?

TW: One advantage is I have a lot of resources targeted for the mission I have. For example, if there's a hazardous materials spill, we have a truck that's all outfitted. I have a guy who's my hazmat expert, and he can provide support to the fire department and police immediately. If there happen to be some pairing bald eagles in the National Arboretum for the first time in nearly 70 years, I've got a bird expert on staff.

When I was on the council, I had to be a quick study for everything, and everybody on staff was pretty close to being a generalist. I certainly had to do a lot of self-study. I became known as the "livable, walkable" guy, and smart growth and new urbanism. My background was social work, but I oversaw a ward that had about $\$ 14$ billion of development. All that came through my office. So I had to provide input that was meaningful for building out the city in a way it had not been built out in 50 years or more. That's why I learned about city planning, pedestrian-oriented development, and human-scale design. I had 
to quickly get up to speed on that.

Running an agency, if I need to get up to speed on something, I have an expert here somewhere. I'm not being asked to do anything I can't do, and that's because the expertise is here. I just point people in the right direction, and sometimes I tell them to march faster, but they go.

\section{PP: Woodrow Wilson wrote in 1887} that public administration is "removed from the hurry and strife of politics," a concept later referred to as the politics-administration dichotomy. Do you think that dichotomy is real, or do the lines between politics and administration blur?

TW: I think it blurs in some ways. I do believe it's my job to promote the mission of the department and use political skills to do that. When we want to heighten interest and bring attention to why we're doing something, that requires political skills. And if we need more resources shifted somewhere, that requires political skills. But one difference is I have a constituency that includes animals, fish, and the integrity of the environment. I'm not trying to win votes. It's easier for me to say no, because that's my job, than for a politician to say no.

And when something happens-say there's an environmental problem-it's my job to come forward and represent the mayor and tell the mayor this is how we fix it. An elected official needs to get in front of people and channel their anger, concern, anxiety, or frustration, and say, "This is terrible. I'm outraged. We're going to make sure this gets fixed." I'm the one who comes forward and says,
"This is why it happened, and it's my job to fix it." So that's where they're different. In almost everything we do there's some political aspect to it. But I'm not there to channel the anger, frustration, or joy of the public. I'm there to execute the values and expectations that have been expressed in the laws of the District.

\section{PP: Initiatives like the Low Income} Home Energy Assistance Program (LIHEAP) provide funds for lowincome residents to pay energy bills, but they do not necessarily promote efficiency. How can we design policies that both address low-income residents' needs and improve efficiency?

TW: One of the first things I saw when I got on the council is that LIHEAP, helping the poor pay their bills for power, is disconnected from-we also have a solar power program and we're investing in efficiencies. But one is treated as a social service program, and the other is treated as an energy capacity program. We also have an emergency program that says if your heater goes out and you're very poor, we'll pay to replace it and have it installed. That doesn't make any sense unless it's connected to weatherization, energy efficiency, and the possibility, depending on where you live, of solar panels on your home. So one of the first things I've done is pushed back the comprehensive energy plan that was being done for the city. I said, "I want you to take a step back and make it really comprehensive." That includes writing a check to someone to help pay their power bill. It's all connected.

But I think it's even broader than that. 
It also includes getting people-in some neighborhoods you can walk to a grocery store, and in other neighborhoods you have to use energy, like gas or a bus, to get to a grocery store. How you view energy is an issue of equity. The more we can get people to use human power-walking, biking - to get where they want, to their doctor's office, to their hair stylist, is equity. It all fits together around energy, looking at energy as a continuum that includes human power. If you live in a place where you have no choice but to drive somewhere, it's not right. If you live in a house where you have no choice but to be getting $\$ 400$ energy bills as you hit winter, that's definitely not equity. So one program that we teed up and launched as soon as I became the director calls for 130 solar roofs in 250 days, free for people with low incomes.

\section{PP: Last year the District Depart-} ment of Transportation released moveDC, a long-range multimodal transportation plan that looks ahead to 2040. In terms of the environment, what big goals do you think the District should aim to achieve by 2040 ?

TW: Without question, we have to get the ozone levels within the federal mandates and goals. We're not attaining the ozone levels now, and they're about to lower them. By 2040 we should have vehicles that are not emitting ozone-causing gases and reduce the number of trips you have to take by a combustion engine through better city planning and amenity distribution. By 2032 we're looking at reducing greenhouse gases related to the city by 50 percent and by 2050 by 80 percent. We don't know how to get there yet, to 80 percent. But we'll be inventing and adopting new ways along the way. More and more people want to live here and raise their families here. Cities can be healthy. I want to see that we've done a lot to make the city healthier. We need to radically increase our tree canopy. Being the director of DDOE I see how incredibly important trees are. Nothing helps to cool the city, control storm water, and improve ozone levels more than trees. So there's a goal of having a 40 percent tree canopy by 2032. I want to do it before then. I want to substantially increase the number of trees we're planting in the city and get smarter about how we do it so they get watered.

\section{$P P:$ When construction began on} the District's streetcar system in 2009 , residents were told that service would begin in 2011 . The start date keeps getting pushed back and there was even speculation that it would be abandoned altogether. What could the city have done better to get the system up and running?

TW: It was poorly managed. The basic functions of getting contracts out the door and planning failed. Engaging the public through the Office of Planning, to show what all the possibilities are, failed. When they first launched the streetcar and put tracks in the ground, it was illegal to run overhead wires in the city. They had no real plan. They just said, "Let's put down tracks, and let's plan as we go." That is an incredibly expensive, hard way to go. A councilmember as a legislator should not be running the streetcar project, as I did in some ways, to keep it going, to keep it funded, and to see that milestones are 
being met.

The thing about streetcars is it's one of the only mass transit systems that pays for itself. When you run a streetcar line, businesses locate along that line, which increases sales taxes; the value of properties goes up, which increases property taxes; and people want to live around streetcar lines, which brings in more income taxes. That funds the streetcar line. I don't care how good the bus system is, businesses don't locate because there's a new bus line, and people don't move because there's a new bus line. It does not pay for itself. Cities that are highly desirable to live in and functional around the world-they have streetcar lines.

We are eventually going to do it, but we've got to look at how to do this in a lot smarter way than this was done and why it cost so much. We need to use the $\mathrm{H}$ Street line as the one to learn from. And the mayor is exactly right to take a step back and say, "How do we do this a lot smarter and a lot better?" This really supports the private sector. But they weren't asked to help lead it, and they weren't asked to help pay for it. In Seattle and Portland, the private sector paid a portion. Here, it was governed horribly and led horribly. I think one day we will have a great system, because, again, it pays for itself.

\section{PP: What about the District's status relative to the federal government (e.g., its lack of voting representation in Congress) frustrates you the most?}

TW: I think what frustrates me the most is when there are leaders in Congress who are so uninformed that they somehow think it's okay to impose their ideological beliefs on a city that can't vote for them. The reason we have a coal plant in a city - which is ridiculous-is purely politics. Representatives from coal-producing states want to force us to have a coal plant, even though it shortens the lives of their own staff or their children. I think the lack of accountability built around ideological ignorance, of leadership being foisted on the District, is horrible. That's what frustrates me the most.

I did my only act of civil disobedience and got arrested when the president, in order to avoid a government shutdown, traded the reproductive rights of women in DC to John Boehner, to the House of Representatives, saying, "John, I will give you DC abortion." Whether you support it or not, the fact that the rights of people in the District can be horse-traded between the legislature and the president, whereas you cannot do that in the states, is pretty horrible. And that's why I went to jail.

\section{PP: You have lived in the District now for 32 years. What are some of the biggest changes that you have noticed since you first moved here?}

TW: When I moved here people were leaving the city in droves. Businesses were closing. City services were becoming substandard. Now people can't move here fast enough. And the expectations for services are much higher. We're no longer a joke. We're an envy. We're attracting the best and the brightest. We are becoming the greenest city in the country. All the elementary schools in the ward I represented have waiting lists of parents 
to get in, because they don't want to leave the city for schools. I think we're becoming truly one of the best places to live in the world, whereas when I first came here in the early 1980s up through the early 1990s, we were the murder capital of the world, we were broke, we were mismanaged, and the services were terrible. I loved living in the city-that's never changed. But a lot of people couldn't get out of here fast enough, and now everybody wants to live here, so it's too expensive for people to come in.

\section{$P P$ : What advice do you have for young people considering or just beginning careers in public policy or public administration?}

TW: I think you have to try to keep yourself in a position to where it's not about making money. You've got to do your best to not incur immediate debt like a car or a house, because the more experience in jobs you can take in public policy, the higher the ceiling you'll have later in your career. In some areas where you would have to start as an intern or a fellow, you find that gives you a leg up on someone who has more education than you, who has other advantages, but you're there and you have the specific type of experience in what you want to do. Try to keep your overhead low so your options are the highest. You'll be able to take experiences that someone else may not be able to take, because they have to pay a debt. That's the first thing.

The second thing is, for as long as you can, you've got to take risks. What you're doing now generally has a lot to do with what you're doing in a year or two years. Definitely what you're doing in two years tells you what you're doing in five. What you're doing in five is what you're doing in ten. Unless there's an intervening variable, and that means changing course. It may mean a new degree. For me it was a law degree. You have to take risks. And you have to have intervening variables, or you are on a line, and if you're okay with the line, then you're alright.

I'm only the director of DDOE because-and I got to tell you, I love this job, it's a fabulous job-but I have it because I took the risk of running for mayor. I lost, but I won a great job. 